\title{
Paradoxical Relationship between Humans, the Environment, And Science in Final Destination (Movies)
}

\author{
Zulkifli Makmur ${ }^{1}$, Muhammad Arsyam², Ardillah $\mathrm{Abu}^{3}$, Andi Muhammad Saleh Alwi ${ }^{4}$, \\ Herianto Herianto ${ }^{5}$, Ibnu Hajar $\mathrm{S}^{6}$ \\ ${ }^{1}$ Sekolah Tinggi Agama Islam (STAI) Darul Dakwah Wal-Irsyad (DDI) Kota Makassar, \\ Indonesia \\ E-mail: zulkifli.makmur@mail.ugm.ac.id \\ ${ }^{2}$ Sekolah Tinggi Agama Islam (STAI) Darul Dakwah Wal-Irsyad (DDI) Kota Makassar, \\ Indonesia \\ E-mail: arsyam0505@gmail.com \\ ${ }^{3}$ Institut Agama Islam Negeri (IAIN) Palu, Indonesia \\ E-mail: ardillah_abu@iainpalu.ac.id \\ ${ }^{4}$ Sekolah Tinggi Agama Islam (STAI) Darul Dakwah Wal-Irsyad (DDI) Kota Makassar, \\ Indonesia \\ Email: aleahm4d@gmail.com \\ ${ }^{5}$ Sekolah Tinggi Keguruan dan Ilmu Pendidikan (STKIP) YAPTI Jeneponto, Indonesia \\ Email: antoherianto47@gmail.com \\ ${ }^{6}$ Sekolah Tinggi Agama Islam (STAI) Darul Dakwah Wal-Irsyad (DDI) Kota Makassar, \\ Indonesia \\ E-mail: dewaibnuhajar@gmail.com
}

\begin{abstract}
.
This study tried to examine the sequels of a movie entitled Final Destination that represent human helplessness and error in facing nature. In the five sequels, both explicitly and implicitly humans leave their traces behind to control nature. To find these traces, the researchers, first, extracted formulas found in the five sequels and then harmonized and compared them to Derrida's deconstruction theory. This research found a paradoxical relationship between humans and science. Humans are considered to have left nature far by being trapped in the ideas and mechanisms of science, which is not expected only to save humans but can also destroy them.
\end{abstract}

Keywords: Final Destination; Deconstruction; Paradox; Environmental Ethics 